\title{
Marion Island volcanism and glaciation
}

\author{
KEVIN HALL ${ }^{1,2}$, IAN MEIKLEJOHN ${ }^{1,4}$ and ADAM BUMBY ${ }^{3}$ \\ ${ }^{1}$ Department of Geography, Geoinformatics and Meteorology, University of Pretoria, Pretoria 0002, South Africa \\ ${ }^{2}$ Current address: Geography Programme, University of Northern British Columbia, 3333 University Way, Prince George, \\ British Columbia V2N 4Z9, Canada \\ ${ }^{3}$ Department of Geology, University of Pretoria, Pretoria 0002, South Africa \\ ${ }^{4}$ Current address: Department of Geography, Rhodes University, PO Box 94, Grahamstown 6140, South Africa \\ hall@unbc.ca
}

\begin{abstract}
Sub-Antarctic Marion Island was the site of extensive volcanism as well as glaciation during both the Quaternary and the Holocene. Initial reconstructions suggested a link between deglaciation and the initiation of faulting which, in turn, facilitated lava eruptions during the interglacials. However, our reassessment of the faulting, volcanic rock, and palaeoglacier distribution indicate that these original interpretations were erroneous. Features thought to be due to faulting are shown to be erosional scarps and this significantly changes interpretations of former glacier distribution. Further, the loss of the former ice cap has revealed new information on former glaciers and their flow directions, thereby allowing reconstruction of palaeoglaciers. Our new reconstruction fits with information from invertebrate genetic mapping that suggest some lava outcrops were nunataks and, therefore, refuges during the Last Glacial period. The new findings of glacial landforms in areas previously covered by snow suggest there was a significant ice advance during the Little Ice Age. Although Holocene volcanic rocks overlie and mask much of the glacial evidence, it has been possible to develop a proposed new reconstruction for glaciation, which is presented together with some of the implications.
\end{abstract}

Received 31 March 2010, accepted 13 September 2010, first published online 22 November 2010

Key words: faulting, glacier reconstruction, glacier-volcanic interactions, palaeoclimate, peri-Antarctic islands

\section{Introduction}

Marion Island (Fig. 1) is located at $46^{\circ} 54^{\prime} \mathrm{S}, 37^{\circ} 45^{\prime} \mathrm{E}$ in the southern Indian Ocean c. $2300 \mathrm{~km}$ south-east of Cape Town and has an area of $290 \mathrm{~km}^{2}$ (Meiklejohn \& Smith 2008 ) with a present day maximum elevation of $1231 \mathrm{~m}$ (Verwoerd 1971, Chief Directorate, Surveys and Mapping 2005). The first glacial chronologies developed for the island were undertaken by Hall (1978a, 1979, 1982), following information from Van Zinderen Bakker et al. (1971). The reconstructions suggested that the island was almost entirely covered by ice (Hall 1978a, 1979, 1982). However, several factors have subsequently been recognized which suggest that the extent of the glaciers may have been less than previously thought. The existence of large periglacial landforms on high lying topography (Nel et al. 2003) required ice-free conditions for longer than proposed in the reconstructions of Hall (1978a, 1979, 1982). This was supported by: 1) a reassessment of glacial distribution in the Long Ridge and Feldmark Plateau areas, 2) new glacial evidence in the Watertunnel Valley, and 3) new glacial evidence in the area of the former 'Ice Plateau', all new observations presented in Chown \& Froneman (2008), particularly in the chapter by Boelhouwers et al. (2008). Furthermore, the existence of invertebrate refugia (e.g.
Katedraalkrans) indicates that certain areas were free of ice during the Last Glacial period (Mortimer et al. unpublished data).

In an ironic twist of scientific fate, the recent paper by Carrivick et al. (2009) reported on the deglaciation induced volcanism hypothesis of Hall (1982), whilst the authors were in the field re-evaluating the glaciation/volcanism interactions of Marion Island. However, although some evidence still indicates volcanism during the interglacials (McDougall et al. 2001), and may have been associated with deglaciation (thereby suggesting the basic hypothesis may still have some merit), the role of faulting identified by Hall (1982) as related to glacier distribution and as providing a lineament along which volcanism occurred, is now found to be in error. What had been identified as faults by a number of geologists (e.g. Verwoerd 1971, fig. 3) in fact show no typical characteristics of faulting, but are rather either palaeosea-cliffs or erosional scarps, probably related to glaciation. This knowledge significantly alters some of the detail regarding palaeoglacier distributions and necessitates reconstructions that take into account the existing scarps (that had previously been thought to be post-glacial in origin, Hall 1982). Commensurate with all of this, the loss of the ice cap on Marion Island (Sumner et al. 2004) that had existed when former glacier distributions were initially reconstructed (Hall 1978a, 1979, 1983), now 


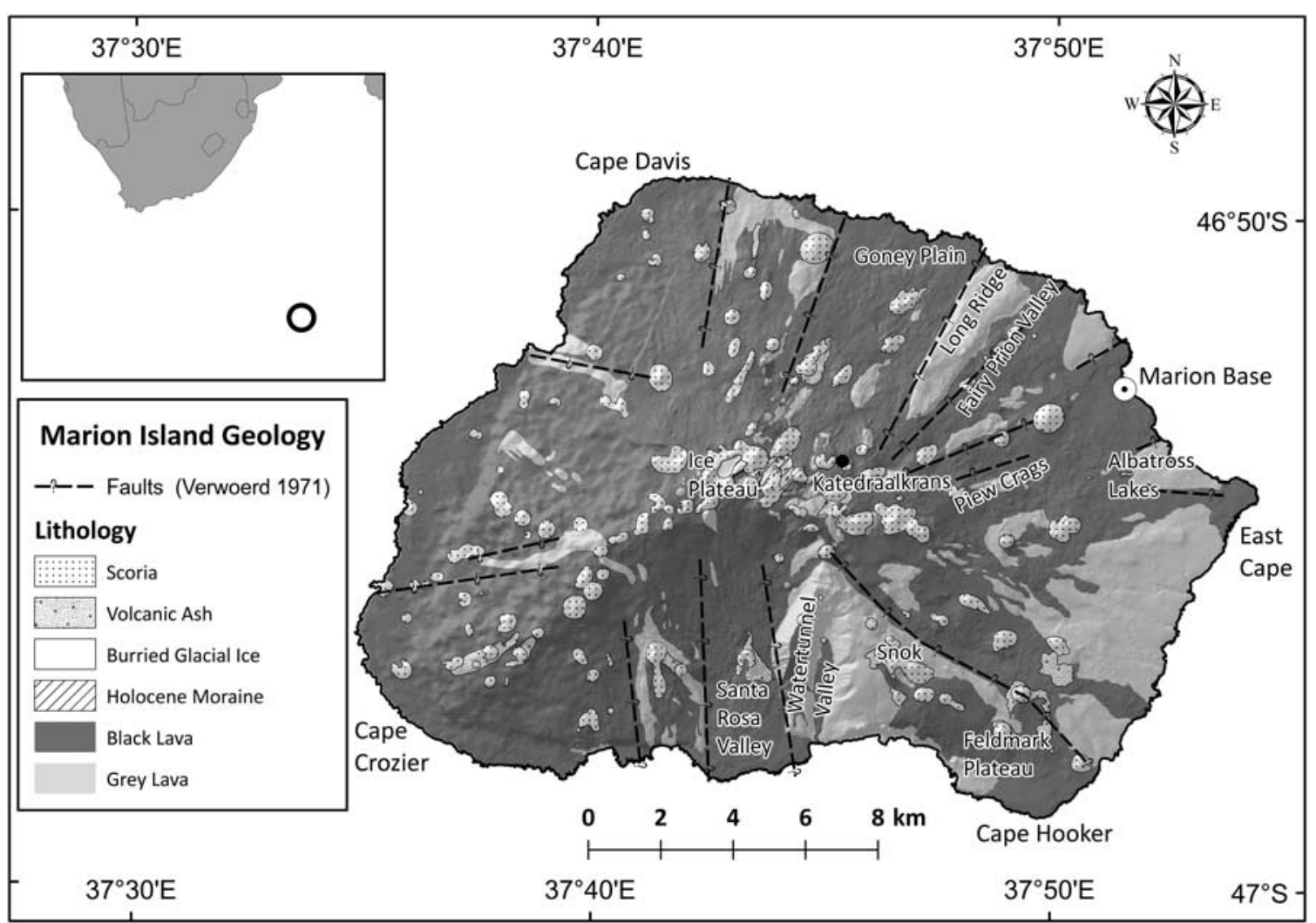

Fig. 1. Location and simplified geology of Marion Island (after Verwoerd 1971, Boelhouwers et al. 2008).

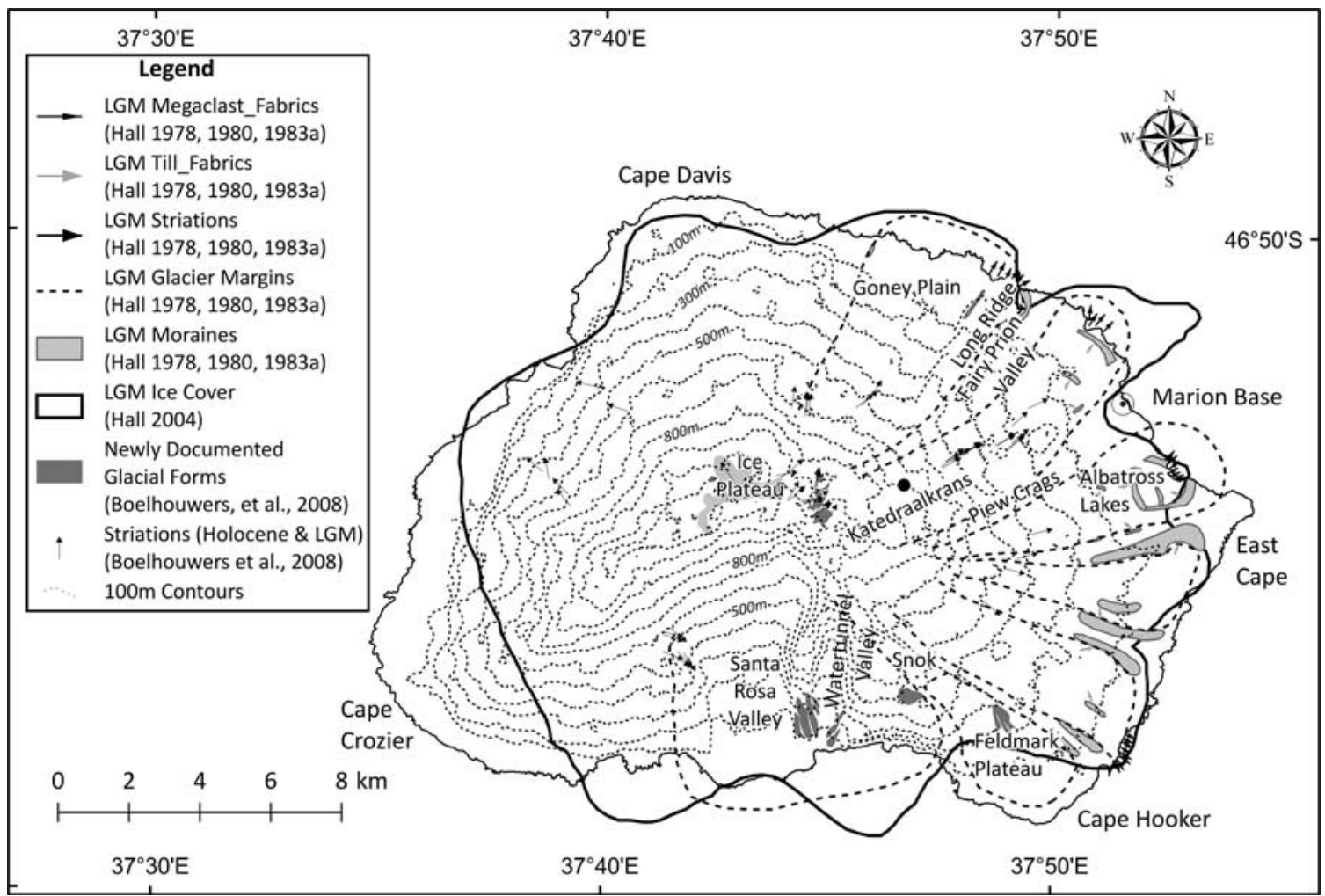

Fig. 2. Glacial evidence and proposed extents of glaciation of Marion Island. 
offers new insights into some palaeoice flow directions and accumulation areas that have to be incorporated with the newly recognized topographical constraints.

All new evidence outlined above is critical to the reassessment of palaeoice distribution and the linkage between deglaciation, faulting and volcanic activity on Marion Island. The reconstructions are seen as being crucial to understanding palaeoglaciations and their links to volcanic chronologies for the sub-Antarctic region as a whole. These new data are presented here together with a new interpretation of palaeoglacier extent on Marion Island.

\section{Synopsis of the original reconstructions}

Marion Island is located close to the edge of the Antarctic plate, but is regarded as being the tip of an intra-plate shield volcano (Verwoerd 1971). Original dates obtained for island (basaltic) lavas were only c. $276 \mathrm{ka}$ (McDougall 1971). The island is composed of two dominant basaltic lava types, which show geochemical characteristics that are typical of oceanic island basalt (Verwoerd 1971, McDougall et al. 2001). Older Pleistocene basalts are referred to as 'grey lavas', the available dates (McDougall 1971) for which in 1982 showed timings that fitted well with known interglacial periods and which frequently exhibit the imprint of glaciation, as described by Hall (1978a, 1979, 1983). The grey lavas are intercalated with sediments considered to be tills. The younger basalts are 'black lavas' from mostly a'a, and also some pāhoehoe flows, all of which are associated with the hundreds of scoria cones that dot the island (Fig. 1) and which impinge upon, or cover, evidence of the last glaciation (McDougall et al. 2001). These lavas are post-glacial as they show no glacial imprint (McDougall et al. 2001), except at the highest elevations in the area known as the 'Ice Plateau' (Boelhouwers et al. 2008).

Palaeoice reconstructions of Marion Island (Hall 1978a, 1979, 1983) were based on evidence from ice moulded and striated bedrock (older, grey lava), glacio-depositional landforms such as moraines, analysis of till sequences (till fabrics, clast shapes and surface features, clast lithological analyses, and pollen analysis) from coastal cliff sections and river cuttings, the perceived linear normal (extensional) faulting and associated post-glacial lava flows, and ice cover that existed at that time (Fig. 2). All the glacial evidence is located on Pleistocene grey lavas (Fig. 1). Glacial reconstruction was, and continues to be, confounded by the post-glacial (black basaltic) lava flows that cover large sections of the island and have thus covered any evidence of glaciation that may have been present. However, the apparent linear alignment of many post-glacial volcanoes, the existence of large grey lava blocks (on some of which the surfaces exhibit glacial activity, e.g. striae) seemingly bounded by fault lines that are along the edges of recent (black) lava flows, and the apparent sequential covering of sediments from each glacial event by lavas (as observed in coastal sections) led Hall (1982) to postulate that there was isostatic response due to rapid deglaciation. As the island is located just to the north of the Antarctic Polar Front, it was subject to rapid ice loss as the Antarctic Polar Front moved south during global post-glacial warming. Faulting was thought to have been induced along the lateral margins of the glaciers thereby facilitating the release of magma, which, in turn, explained the present day radial distribution of volcanoes and large faults. Inferred peripheral faults (now covered by the recent black lavas), normal to the radial faulting, due to the ice rapidly retreating inland, were used to explain the step-like topography of the island (Hall 1982). Unknown to Hall (1982), work by Grove (1974) had already reported deglaciation as a trigger mechanism for volcanism based on evidence from Canada. Grove (1974, p. 88) had argued that 'periodic deglaciation involving the rapid removal of a considerable hydrostatic load from fissure zones had triggered basaltic volcanism during the Neogene' and hence 'in continental areas....deglaciation should be considered as another mechanism...f for triggering volcanism'. Thus, although the larger-scale, continental deglacial triggering mechanism had already been suggested, the observations from Marion Island were still new insofar as they applied to a smaller-scale setting.

\section{New evidence regarding faulting and implications for landforms}

Initial interpretations of the topography on Marion Island suggested that the large-scale escarpments (up to $300 \mathrm{~m}$ relief) that radiate from the interior of the island towards the coast could have formed from a radial pattern of normal (extensional) faulting (Verwoerd 1971, Chevallier et al. 1992). In a normal fault, crustal extension allows the hanging wall of the fault to drop down, so that the footwall forms an escarpment in the topography. This type of faulting could ordinarily be expected around a volcanic edifice, subjected to a radial extension during successive volcanic eruptions (e.g. Peacock \& Parfitt 2002). As an example, the NE-SW trending Long Ridge, in the northeast of the island (Fig. 1), was interpreted as a typical horst, bound to the north-west and south-east by a conjugate pair of normal faults dipping in opposite directions away from the ridge (Verwoerd 1971). Adjacent low-lying areas such as Goney Plain and Fairy Prion Valley were envisaged to be underlain by the fallen hanging wall block (Fig. 1). This interpretation was based purely upon the topographic expression of the ridge, without any detailed structural geological investigations (Hall 1982).

Recently, as part of this study, a survey of planar structures exposed in cliffs along all escarpments was 



Fig. 3. Photographs showing examples of slickenside lineations accommodating millimetre- to centimetre-scale displacement, preserved only rarely in basalt on Marion Island.

undertaken across Marion Island. However, little evidence could be found to support faulting on a sufficiently largescale to account for any of the Marion Island escarpments. If the basalt on Marion Island had been subjected to largescale faulting, such as that required to produce a horst at Long Ridge, such fault surfaces would be characterized by well-developed cataclasite or fault breccia. However, not one example of this was found anywhere on Marion Island.

Instead of being occupied by fault surfaces, the cliffs along the escarpments are characterized by well-preserved columnar jointing formed by contraction during the cooling of the lava, and exceptionally few of these joint surfaces appear to accommodate any subsequent fault movement. The only evidence for active faulting found on Marion Island were a limited number of slickensided fault planes (Fig. 3) with a wide variety of orientations and senses of slip (normal, reverse and strike-slip). These were found in both black and grey lavas across the island, and always in isolation (i.e. not in neighbouring, sub-parallel sets of planes), not characterized by development of any substantial thicknesses of cataclasite or fault breccia along their surfaces, and not concentrated near to any escarpments. Slickenside lineations such as these can

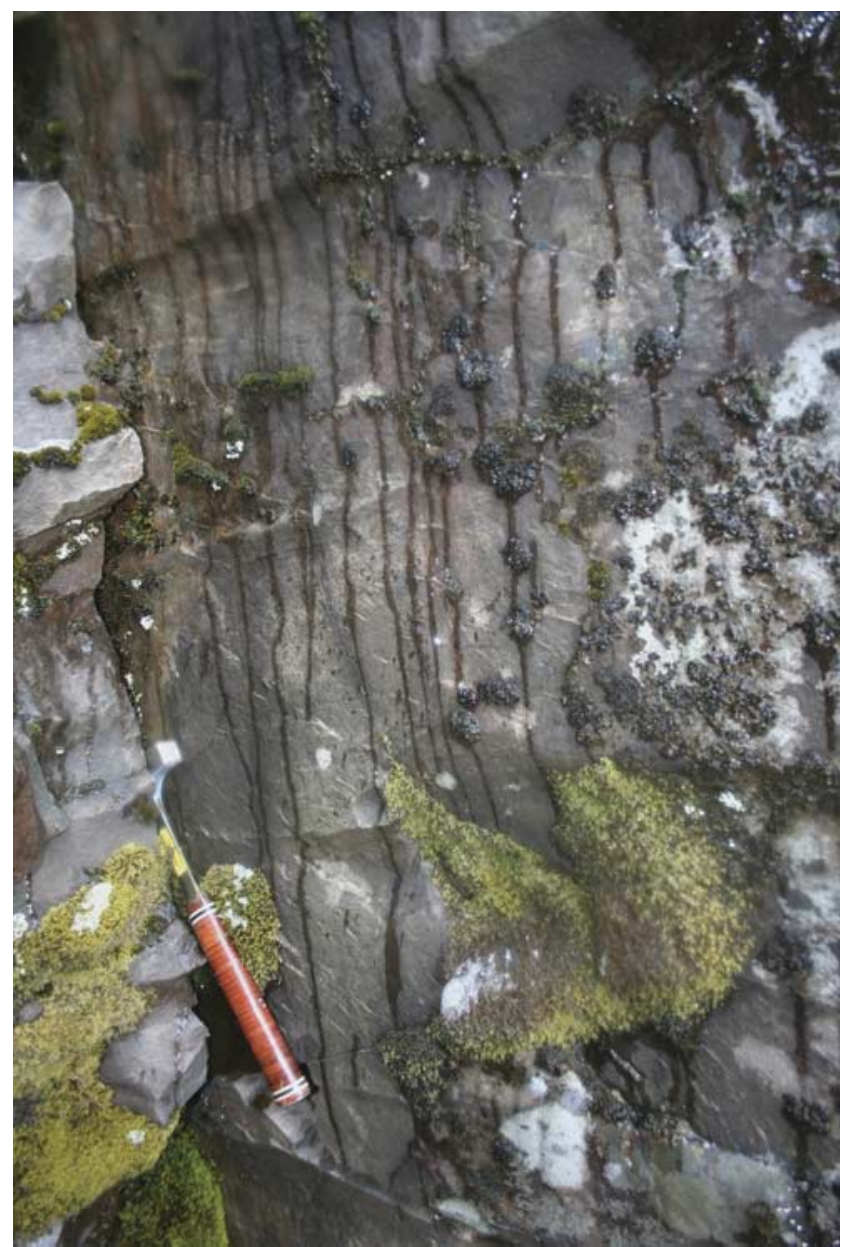

Fig. 4. Face of a large-scale columnar joint on the south-east escarpment of Long Ridge, showing preserved banding and feint ribbing, associated with the propagation of cooling joints in lava. Such unfaulted joint faces are typical along the entire length of both the south-east and north-west escarpment cliffs of Long Ridge.

form during as little as $2 \mathrm{~mm}$ displacement (e.g. Means 1987), and individual slickenside planes which have not been reactivated are thought to accommodate only up to 10-20 cm of movement (e.g. Twiss \& Moores 1992), and are therefore unlikely to have accounted for a significant amount of displacement such as that required to produce the escarpments on Marion Island.

Long Ridge serves as an excellent example of the absence of such relationships. It is characterized by up to $300 \mathrm{~m}$ of relief with cliffs reaching a height of up to $100 \mathrm{~m}$. Nowhere along these outcrops were any fault planes with significant displacement found, and the full extent of the cliffs is instead characterized by columnar jointing (Fig. 4). Even supposing that a fault plane accommodating a $300 \mathrm{~m}$ displacement could have been removed locally by erosion or rock fall, if Long Ridge is indeed a horst structure, at least some evidence for faulting would have been preserved 


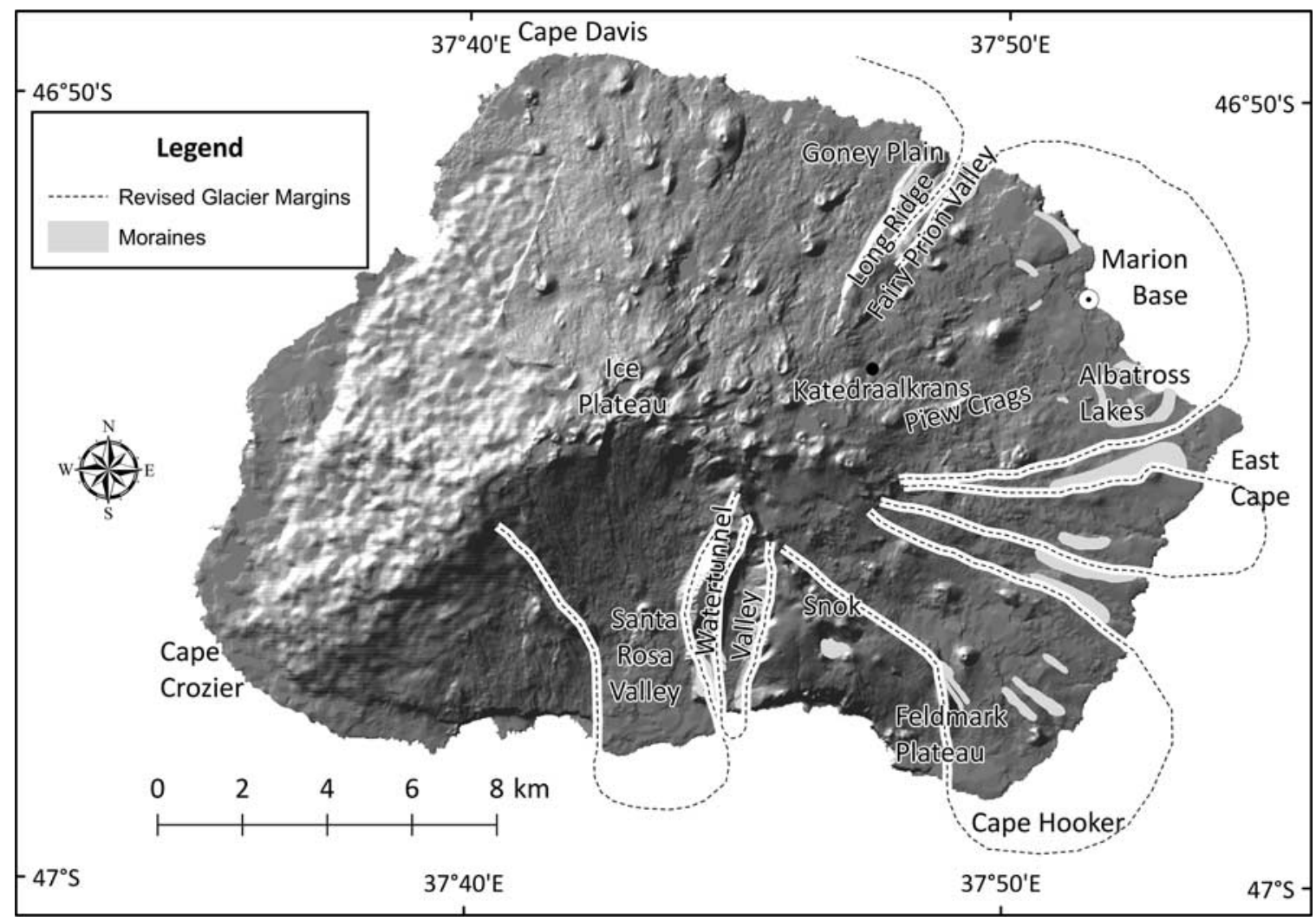

Fig. 5. Amended interpretation of glacial margins for the last glaciation of Marion Island.

amongst the extensive outcrops along the length of the ridge. Thus, the absence of any evidence of large-scale faulting along Long Ridge suggests that Hall's (1982) notion that Long Ridge is a horst structure is extremely unlikely to be true.

The relationship between deglaciation and normal faults described by Hall (1982), where normal faulting (and subsequently volcanism) could have initiated as an isostatic response to unloading of glacial ice, can also be considered unlikely in terms of fault theory (e.g. Anderson 1951), as deglaciation would have led to a stress field that is inappropriate for the formation of normal faults. Typically normal faulting is associated with horizontal extension, whereas rapid deglaciation would have produced vertical extension during the concomitant isostatic adjustment. In Iceland, recent deglaciation has been accompanied by 9-25 $\mathrm{mm} \mathrm{yr}^{-1}$ vertical uplift, with merely $3-4 \mathrm{~mm} \mathrm{yr}^{-1}$ horizontal extension (Pagli et al. 2007b), demonstrating that isostatic extension during deglaciation is vertically orientated, rather than horizontal, and would not lead to normal faulting, or any horst and grabens that had been envisaged to account for the escarpments on Marion Island.

Although normal faulting is unlikely to be associated with deglaciation, normal faulting is well known to be associated with volcanism (e.g. Peacock \& Parfitt 2002, Pagli et al. 2007a) and is found on many volcanoes, irrespective of any glacial history on a volcano. Volcanic islands which are exposed on the top of a submarine edifice of phreatomagmatically erupted tephra, are generally prone to listric (rotational) normal faulting due to gravitational collapse of these deposits as the volcanic edifice builds up, and volcanoes can also be affected by normal faulting around the rim of calderas due to evacuation of the magma chamber beneath (e.g. Pagli et al. 2007a). However, these normal faults do not directly owe their activation (or reactivation) to isostatic adjustment following deglaciation. Thus, although there might well be a temporal link between volcanic events and the limited history of faulting on Marion Island, it is difficult to envisage that deglaciation could have prompted that faulting, as suggested by Hall (1982).

\section{New topographic/volcanic characteristics that must be accommodated in reconstructions}

Given a central ice cap with warm-based ice flowing out to the lower coastal areas of Marion Island, maximum dissipation of gravitational energy means that ice will flow into and along topographic lows, as would any lava. It is clear that current areas of relatively high relief (e.g. Long Ridge \& Piew Crags, see Fig. 1) show multiple lava flows and that additionally many, at their coastal ends, have tills. 


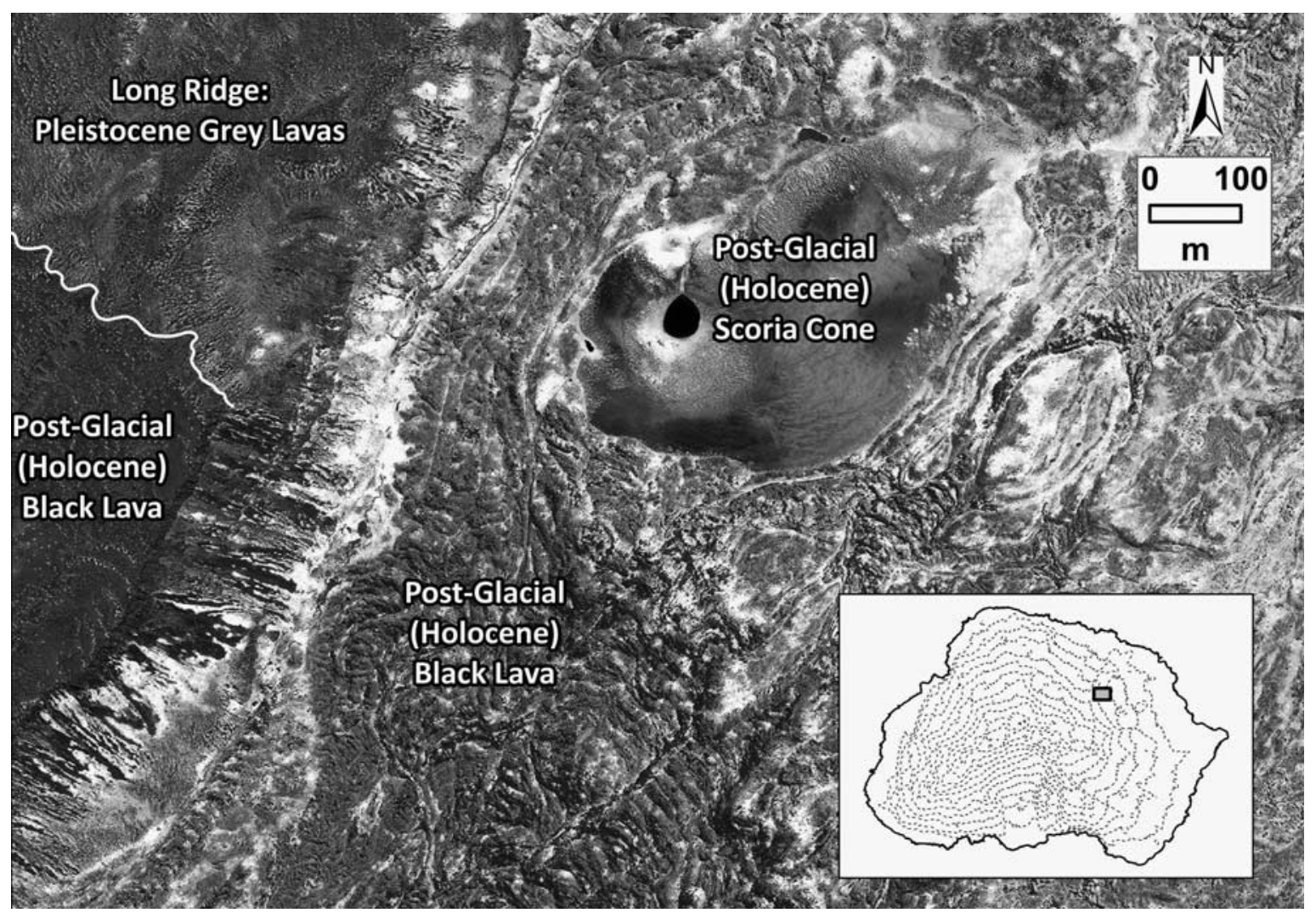

Fig. 6. QuickBird image showing Pleistocene grey lavas of Long Ridge (which was glaciated at the Last Glacial event), and postglacial volcanism in the form of a scoria cone and black lava flows (image courtesy of Digital Globe ${ }^{\circledR}$ ).

The implication is that these areas must have been areas of relatively low relief during both the glacial and the volcanic events. The synclinal attitude of the lava beds in Long Ridge attest to this being adjacent to higher relief and, consequently of low relief during the period of the lava outpourings and glacial events. That these (previous lows) are now significant highs within the landscape and exhibit erosional lateral exposures, identifies that material must have been removed. In the case of such as Long Ridge which terminates at the coast, the coastal cliffs are a result of marine erosion. The most recent black basaltic lava flows fill in the lows between these topographic highs, areas it is now assumed must also have contained glaciers during the preceding glacial event (Fig. 6). Thus, there is the requirement in any reconstruction to identify the present ridges as (relative) low points for extensive periods to accommodate the successive lava flows and/or tills, previously identified by Hall $(1979,1982,1983)$. It must also be noted that the areas of most recent lava flows, as present topographic lows, must have been covered by glaciers (the evidence of which they now cover). Also, if the highest points in the central part of the island are postglacial in origin (as is here considered), so the former summit of the island was probably lower, such that some of the grey lava flows (e.g. Kateldraalkrans, see Figs $2 \& 5$ ) were possibly nunataks at the margin of the former central ice basin. Further, the margins of the island were not as they now appear, as coastal margins during glaciation were substantially seaward due to lower sea levels. Lastly, postglacial lava flows have added to parts of the coast while coastal erosion during rising sea levels (Hall 1978a) has cut back some areas.

The most recent research based on $\mathrm{K}-\mathrm{Ar}$ geochronology on Marion Island suggests eight periods of volcanic activity (McDougall et al. 2001), rather than the initially proposed three (McDougall 1971). McDougall et al. (2001) argued that periods of earlier volcanic activity coincided with glaciations, they suggested that the two most recent volcanic episodes are interglacial in timing (Fig. 7). Overall, their proposed chronology still indicates a strong relationship between volcanic events and interglacial periods (McDougall et al. 2001, fig. 9, p. 14). Further, McDougall et al. (2001) based their timings for Marion Island glacial events on those of the Northern Hemisphere (notably the western USA) and, although there may be some degree of synchronicity, it is thought unwise to use these in too rigorous a manner for the sub-Antarctic (an oceanic situation in the other hemisphere). Nevertheless, it is certainly clear that the relationship of deglaciation to volcanism is not as simplistic as was thought by Hall (1982). 


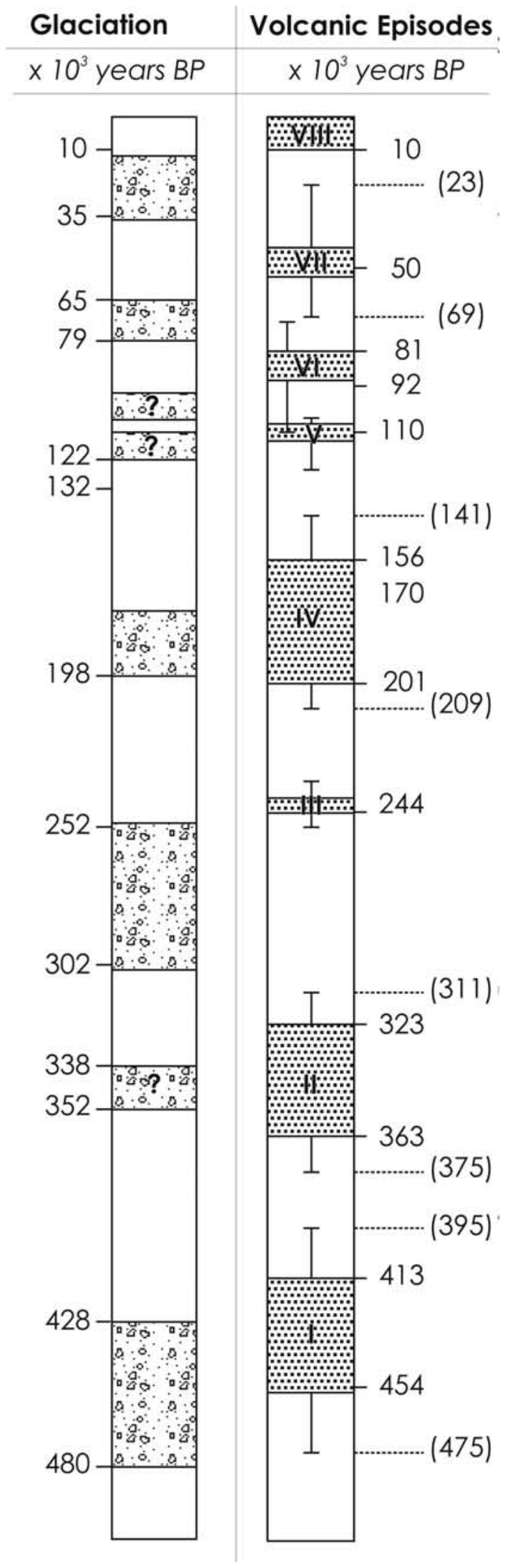

Fig. 7. Glacial and volcanic chronology from Marion Island (after McDougall et al. 2001, Boelhouwers et al. 2008).
Glacier reconstructions in the light of the new evidence

Whereas the broad picture of glaciation as presented by Hall (1978a, 1979) remains, changes are required that reflect different boundaries to the previously suggested glacier cover. That faulting is no longer viewed as coexisting with deglaciation, requires that the glacier margins from the Last Glacial period are re-evaluated. Primarily, the result of the new reconstruction is to increase the lateral extent of some glaciers while, elsewhere, to separate what was thought to be a single glacier into several. The area between Long Ridge and Albatross Lakes, was previously thought to be impacted by three glaciers, with intervening ice-free sections (Fig. 2). Given that no faulting occurred over this entire area, the modelled ice coverage now requires one glacier. Further, the northern boundary of this glacier is the south side of Long Ridge. The southern boundary of the Long Ridge glacier is now to the northern edge of Long Ridge, not the south as was previously thought. At (proposed) maximum glacier extent, it would seem likely that the island was covered by a large ice mass that only differentiated into some semblance of individual glaciers near to their terminal margins (Fig. 5). As the ice retreated so some higher degree of separation may have taken place but evidence for this has been lost under the post-glacial lava flows. The post-glacial lava flows (black lavas) are clearly topographically constrained (Fig. 6) and show none of the evidence presented by Lescinsky \& Sisson (1998), Lescinsky \& Fink (2000), or Lodge \& Lescinsky (2009) of lava flows being in contact with, constrained by, or bounded by ice. It is clear that at lower altitudes on Marion Island the most recent lava eruptions (post-glacial) occurred after the ice had melted.

The argument (Hall 1978a) that glaciation was brought on by an increased precipitation in the form of snow coupled with a slight drop in temperatures as the Antarctic Polar Front moved north would still seem acceptable. With such a scenario, glaciation was maintained by a large snow input and ablation could still be substantial. If this were so, then it remains possible that areas such as Katedraalkrans (Fig. 5) may not have been covered by ice and would have been a nunatak, as has been suggested by Mortimer et al. (unpublished data) based on phylogeographic studies of insects. Indeed, that Schalke \& Van Zinderen Bakker (1971) and Chown \& Froneman (2008) found that various biota survived the glaciations so the idea of a nunatak refugia would seem appropriate (Chown \& Froneman 2008, p. 354).

Another repercussion of the new reconstruction is that the palaeotemperatures calculated by Hall (1979, table 1) and equilibrium line altitudes (ELA) and accumulation area ratios (AAR) (Hall 1983) must now have some (greater) errors within them. Maximum island elevations were lower than at present, but glaciers, now considered much larger than previously thought, probably extended much further seaward than was first anticipated (Hall 1983, fig. 1). 
As noted previously (Hall 1979, p. 254) any seaward reconstruction of the glaciers is highly contentious as (to date) there are no offshore data. However, the thick tills at the present coastal margins (Hall 1983, fig. 2) suggest no reason why extensive seaward growth, during these times of lower glacial sea levels, should not have taken place. Indeed, the increased seaward projection of palaeoglaciers would make better sense of the observed extensive (both laterally and vertically) coastal till sections.

\section{Summary: implications of the new glacial-volcanic reconstruction}

Although there are situations where the glacial isostaticvolcanic theory of Hall (1982) appears to function (Carrivick et al. 2009), it is now clear that the original evidence in favour of this idea for Marion Island is in error and that, in the absence of any other information, there is no apparent formal linkage between deglaciation and volcanism on Marion Island. The main findings are thus twofold: first, that there is very little evidence for faulting, and second, that volcanism is not solely during interglacials. The repercussions of this are that: 1) the many radial scarps must have been existent during glaciation, 2) what are now ridges must have been relative lows during both glaciation and volcanism, 3) that present lows filled with lavas must have beneath them glacial material(s), 4) there were possible nunataks during the Last Glacial episode, and that, as a consequence of all the preceding, 5) glacier distribution differed somewhat from that originally postulated. Is this a large and significant change in terms of glacial reconstruction? Perhaps not, but it does (indirectly) provide some valuable information and, at the same time, beg a number of interesting questions. Additionally, observations of 'fresh' (i.e. showing no signs of weathering) striations on basalts exposed by the recent ice cap loss suggest that, contrary to earlier thoughts (e.g. Hall 1979), there may have been an expansion of the ice cap during the Little Ice Age. With the loss of the ice cap and easier logistical access to the higher elevations of the island, new findings of (seemingly) freshly striated surfaces and moraines on what appear to be recent lava flows, suggests that the ice expanded seaward during that period. However, in the absence of dates specific to the lavas and of any higher elevation depositional landforms this, perhaps not unexpected, Little Ice Age expansion can be neither verified or mapped yet.

The new glacial reconstruction provides support for the hypothesis of ice-free refugia (nunataks) thereby validating the initial ideas of Schalke \& Van Zinderen Bakker (1971) and, in turn, the site(s) identified by phyllogeographic and genetic studies (Chown \& Froneman 2008) for such refugia. Ice-free conditions at these refugia may also explain why periglacial landforms, such as solifluction terraces and sorted patterned ground, at these locations are physically larger than elsewhere on the island. Nel et al. (2003) questioned whether a longer exposure of these environments to ice-free conditions may have produced bigger periglacial landforms than the same features elsewhere on the island, where ice cover is certain. The occurrence of volcanism during glacials on Marion Island also offers further possibilities that, through geothermal heating, nunataks became refugia, but this is something still in need of better understanding and identification.

Scoria eruptions during the glacials helps explain fluctuations in scoria content within tills and, in some instances, the extremely high $(>40 \%)$ scoria content found for lodgement till (Hall 1978b) 'midway' during the glacial sequence (Fig. 7). These deposits are clearly lodgement tills (Hall 1978) and did not result from subglacial eruptions and the discharge of meltwater as described by Smellie (2002) on Deception Island. Indeed, the now proven (McDougall et al. 2001) occurrence of volcanism during glacial episodes (Fig. 7) helps answer many of the problems in defining glacialsedimentological boundaries encountered by Hall (1978b) in the initial investigation. On the other hand, knowledge that the significant scarps on the island are not tectonic does raise questions as to the development of the current 'inverted topography'. Another question relates to ice distribution during glacials preceding the Last Glacial event and the location of earlier topographic lows for both lava and ice flows, and how these relate to the development of the island relief through time. In many ways, Marion Island serves as a possible model for the reconstruction of glacial-volcanic interactions elsewhere in the sub-Antarctic (Hall 2004). The extensive work by Smellie (e.g. Smellie 2000, 2001), and Hambrey et al. (2008) regarding interactions between volcanism and ice cover has no direct applicability to this study as presented here, notably because here we have no knowledge regarding subglacial volcanic events or of the necessary lithofacies details, but some of their findings may suggest future lines of research relating to detailed studies of the volcanoclastics and lavas (as suggested extensively by one referee).

\section{Acknowledgements}

For the ability of $\mathrm{KH}$ to return to Marion Island after 35 years I would like to thank Prof Ian Meiklejohn and the South African National Antarctic Programme. The University of Northern British Columbia helped $\mathrm{KH}$ with some of the travel costs associated with undertaking this work. In the field it was a great pleasure for KH to work with both Ian Meiklejohn and Adam Bumby, as well as Barend van der Merwe and Mphumzile Zilindile - the more so for their patience during the long walks in the field! Werner Nel's and David Hedding's comments and ideas in the field on previous expeditions are appreciated (IM \& $\mathrm{AB})$. Funding for the project was provided by the National Research Foundation Grants SNA2005061300001 (IM) and SNA2008050800005 (AB). Logistical support was provided by the South African National Antarctic Programme of the Department of Environmental Affairs and Tourism, South Africa. We would like to thank Professor B. Whalley and a 
number of anonymous referees for their multiple and varied thoughts, suggestions and comments that greatly helped in the rewrites of this paper.

\section{References}

Anderson, E.M. 1951. The dynamics of faulting. Edinburgh: Oliver \& Boyd, 206 pp.

Boelhouwers, J.C., Meiklejohn, K.I., Holness, S. \& Hedding, D.W. 2008. Geology, geomorphology and climate change. In Chоwn, S.L. \& Froneman, P.W., eds. The Prince Edward Islands: land-sea interactions in a changing ecosystem. Stellenbosch: African Sun Media, 65-96.

Carrivick, J.L., Russell, A.J., Rushmer, E.L., Tweed, F.S., Marren, P.M., Deeming, H. \& Lowe, O.J. 2009. Geomorphological evidence towards a de-glacial control on volcanism. Earth Surface Processes and Landforms, 34, 1164-1178.

Chevallier, L., Verwoerd, W.J., Bova, P., Stettler, E., Du Plessis, A., Du Plessis, J.G., Fernandez, L.M. \& Nel, M. 1992. Volcanological features and preliminary geophysical investigations on Marion Island. South African Journal of Antarctic Research, 22, 15-35.

Chief Directorate, Surveys \& Mapping. 2005. Marion Island. 1:25 000. Provisional map, May 2005. Mobray: Chief Directorate, Surveys \& Mapping.

Chown, S.L. \& Froneman, P.W. eds. 2008. The Prince Edward Islands: land-sea interactions in a changing ecosystem. Stellenbosch: African Sun Media, $470 \mathrm{pp}$.

Grove, E.W. 1974. Deglaciation - a possible triggering mechanism for recent volcanism. In Gonzalez-Ferran, O., ed. Proceedings of the Symposium on Andean and Antarctic Volcanology Problems. Rome: IAVCEI, 88-97.

HaLL, K.J. 1978a. Evidence for Quaternary glaciation of Marion Island (sub-Antarctic) and some implications. In VAN ZiNDEREN BAKKeR, E.M., ed. Antarctic glacial history and world palaeoenvironments. Rotterdam: Balkema, 137-147.

HaLL, K.J. 1978b. Quaternary glacial geology of Marion Island. PhD thesis, University of the Orange Free State, 369 pp. [Unpublished.]

HaLl, K.J. 1979. Late glacial ice cover and palaeotemperatures on subAntarctic Marion Island. Palaeogeography, Palaeoclimatology, Palaeoecology, 29, 143-159.

HaLl, K.J. 1982. Rapid deglaciation as an initiator of volcanic activity: an hypothesis. Earth Surface Processes and Landforms, 7, 45-51.

HaLl, K.J. 1983. A reconstruction of the Quaternary ice cover of Marion Island. In Oliver, R.L., James, P.R. \& J JGO, J.B., eds. Antarctic earth science. Canberra: Australian Academy of Science \& Cambridge: Cambridge University Press, 461-464.

HaLl, K.J. 2004. Quaternary glaciations of the sub-Antarctic islands. In Ehlers, J. \& GibBard, P.C., eds. Quaternary glaciations: extent and chronology. Part III: South America, Asia, Africa, Australia, Antarctica. Amsterdam: Elsevier, 339-346.

Hambrey, M.J., Smellie, J.L., Nelson, A.E. \& Johnson, J.S. 2008. Late Cenozoic glacier-volcano interaction on James Ross Island and adjacent areas, Antarctic Peninsula region. Geological Society of America Bulletin, 120, 709-731.

Lescinsky, D.T. \& Fink, J.H. 2000. Lava and ice interaction at stratovolcanoes: use of characteristic features to determine past glacial extents and future volcanic hazards. Journal of Geophysical Research, 105, 23711-23726.
Lescinsky, D.T. \& Sisson, T.W. 1998. Ridge-forming, ice-bounded lava flows at Mount Rainier, Washington. Geology, 26, 351-354.

Lodge, R.W.D. \& Lescinsky, D.T. 2009. Fracture patterns at lava-ice contacts on Kokostick Butte, OR, and Mazama Ridge, Mount Rainier, WA: implications for flow emplacement and cooling histories. Journal of Volcanology and Geothermal Research, 185, 298-310.

McDougall, I. 1971. Geochronology. In Van Zinderen Bakker, E.M., Winterbottom, J.M. \& Dyer, R.A., eds. Marion and Prince Edward Islands. Cape Town: Balkema, 72-77.

McDougall, I., Verwoerd, W. \& Chevalier, L. 2001. K-Ar geochronology of Marion Island, Southern Ocean. Geological Magazine, 138, 1-17.

Means, W.D. 1987. A newly recognized type of slickenside striation. Journal of Structural Geology, 9, 585-590.

MeiкLejohn, K.I. \& Sмith, V.R. 2008. Surface areas of altitudinal zones on sub-Antarctic Marion Island. Polar Biology, 31, 259-261.

Nel, W., Holness, S. \& Meiklejohn, K.I. 2003. Observations on rapid mass movement on sub-Antarctic Marion Island. South African Journal of Science, 99, 177-181.

Pagli, C., Sigmundsson, F., Pedersen, R., Einarsson, P., Árnadóttir, T. \& FeIGL, K.L. 2007a. Crustal deformation associated with the 1996 Gjálp subglacial eruption, Iceland: InSAR studies in affected areas adjacent to the Vatnajökull ice cap. Earth and Planetary Science Letters, 259, 24-33.

Pagli, C., Sigmundsson, F., Lund, B., Sturkell, E., Geirsson, H., Einarsson, P., Árnadóttir, T. \& HreinsdóttiR, S. 2007b. Glacioisostatic deformation around the Vatnajökull ice cap, Iceland, induced by recent climate warming: GPS observations and finite element modelling. Journal of Geophysical Research, 112, 10.1029/ 2006JB004421.

Peacock, D.C.P. \& Parfitt, E.A. 2002. Active relay ramps and normal fault propagation on Kilauea Volcano, Hawaii. Journal of Structural Geology, 24, 729-742.

Schalke, H.J.W.G. \& van Zinderen BaKker, E.M. 1971. History of the vegetation. In VAN ZindeREN BAKKeR, E.M., WinterbotToM, J.M. \& DYeR, R.A., eds. Marion and Prince Edward Islands. Cape Town: Balkema, 89-99.

Smellie, J.L. 2000. Subglacial eruptions. In Sigurdsson, H., ed. Encyclopedia of volcanoes. San Diego, CA: Academic Press, 403-418.

SMELLIE, J.L. 2001. Lithofacies architecture and construction of volcanoes in englacial lakes: Icefall Nunatak, Mount Murphy, eastern Marie Byrd Land, Antarctica. In White, J.D.L. \& RigGs, N., eds. Lacustrine volcaniclastic sedimentation. International Association of Sedimentologists, Special Publications, 30, 73-98.

Smellie, J.L. 2002. The 1969 subglacial eruption on Deception Island (Antarctica): events and processes during an eruption beneath a thin glacier and implications for volcanic hazards. In SMeLLIE, J.L. \& Chapman, M.G., eds. Volcano-ice interaction on Earth and Mars. Geological Society, London, Special Publications, No. 202, 59-79.

Sumner, P.D., Meiklejohn, K.I., Boelhouwers, J.C. \& Hedding, D.W. 2004. Climate change melts Marion Island snow and ice. South African Journal of Science, 100, 395-398.

Twiss, R.J. \& Moores, E.M. 1992. Structural geology. New York: W.H. Freeman, 532 pp.

VAn Zinderen Bakker, E.M., Winterbottom, J.M. \& Dyer, R.A. 1971. Marion and Prince Edward Islands. Cape Town: Balkema, 427 pp.

Verwoerd, W.J. 1971. Geology. In VAN Zinderen BakKer, E.M., Winterbottom, J.M. \& Dyer, R.A., eds. Marion and Prince Edward Islands. Cape Town: Balkema, 40-61. 